\title{
Glory Style in Mandar Song Lyrics: A study of Mandar Tribe in South Sulawesi, Indonesia
}

\author{
Mutmainnah \\ Universitas AL Asyariah Mandar, Indonesia \\ Andi Asrifan \\ STKIP Muhammadiyah Rappang, Indonesia \\ Sulihin Azis \\ Universitas AL Asyariah Mandar, Indonesia \\ Ulfa Maulidya \\ Universitas AL Asyariah Mandar, Indonesia
}

\begin{abstract}
This research background of how the style of language in the lyrics of Mandar song because of today many of the Mandar song lovers who lack understanding of the meaning that is in the lyrics Mandar song. The purpose of this research was to describe the fact of lyrics and identify the style of language in the lyrics of the song Mandar. This research applied descriptive qualitative research method. Descriptive research was a research procedure that produces descriptive data in the form of written words about the nature of individuals, circumstances, symptoms of certain groups that can be observed. The study, which began in September 2015 to January 2016, was unbound by space. In this study, it was found that the most commonly used hyperbola, asonation, and repetition style. Concluding remarks of the study were 174 lyric styles consisting of 8 personatic language styles, 6 metaphorical language styles, 7 simile / comparison language styles, 10 depersonative language styles, hyperbolic language styles, 7 parallelism languages, 4 style alliteration, 109 asonance and 17 repetition language styles.
\end{abstract}

Keywords: Language Style, Mandar Song Lyrics.

\section{A. INTRODUCTION}

Kridalaksana, (1984: 19) stated that "Language is an arbitrary system of symbolic sounds, used by members of society to cooperate, interact, and self-identity." Language function is a tool for communication. Language as a means of communication has provided a lot of knowledge for human beings in various fields. It happens because all kinds of fields of science learned by mankind, all using language as an introduction. It is impossible for science to be socialized without language. One of the essences of language is that language is dynamic. Dynamic, in the context of the essence of language according to Chaer (2002: 17) report that "the language is inseparable from the various possible changes that can happen at any time. That change can occur at all levels of linguistics ".Therefore, the language will undergo continuous development in accordance with the development of human thought and needs as a language user. In addition to language, culture can also develop at any time. With another word, language and culture can together develop in accordance with the development of an increasingly advanced era. Any language development, either in the form of a change of meaning, addition or replacement, is still regarded as a development in the language. Therefore, as intelligent, educated, knowledgeable, and cultured beings, human beings are able to explore various kinds of creativity and innovation so as to create a masterpiece that is good and loved by many people. We may use dialogue both orally and in writing to interact with others. However, in the activity interacting there are various variations that can be used by humans when they do language activities in community life. Not only in the form of dialogue but over the times there are also in singing a song, musical poetry and also poetry. This is language activity Because there is aninteraction between the reader with the listener. The interaction occurs because of a message from the reader or singer, to the listener as the recipient of the message. As Chaer pointed out (2002: 2) that "language activity is an act of expressing the symbols of language to convey the meanings of the symbol, to its interlocutor in oral communication, or readers (in written communication)."The ability of humans to explore creativity in the process of language causes a lot of created works of high value and favored by many people. From the works of human creation, many works that use language as medium .but with the varying levels of human imagination, then varied human creations when poured in the form of words, so that between one work with other works will have its own characteristics, one of which is in terms of word selection (diction).

Today, one of human creativity that stands out varies, and of course, uses language as its medium is in the field of sound art, which people generally call it with song terms. In making a song, there are two important things that are very supportive and must be considered the lyrics as a language and music as a companion. The lyrics are a work art that has a sensed value. Song lyrics can make a person thrilled at the heart when hearing what if it contains a high aesthetic value. This beauty is deliberately created by a composer to captivate his fans. The beauty of the cause is to pay attention to the style of language, diction, and rhythm that is used. All of that can reveal the fascination of a composer who has imagination and thought as a songwriter. This is consistent with the opinion of Keraf (2000: 113) which said that "the way of expressing the mind is through language typically showing the soul and personality of the Author." The reason why the author chose the title is that the object of study in the form of song lyrics, used to be analyzed about the style of language, then this

1286 | P a g e

November 2017 
research is done because it useslanguage as the main media. That's the curiosity of the researcher to find out what language style is used in the lyrics of Mandar's song.

1. The problem of the study

Based on problem identification and problem restrictions that have been determined by the author, then the problem to be examined by the author is, "How is the language style of the lyrics of Mandar song?"

2. The Objective of the study

The purpose of this study is to describe the facts in the form of lyrics and identify appropriate language styles

3. The significance of the study

Usefulness this research is expected to be useful for Mandar lovers can know that Mandar song has a deep meaning.

a. Theoretical benefits

Theoretically this research is expected to give an idea about the style of language used in Mandar song lyrics.

b. Practical Benefits

Creating a Mandar song lovers community better understand the style of language in the lyrics of the song Mandar and Help the community of music lovers more critical response to Mandar songs.

\section{B. LITERATURE REVIEW}

1. Stylistic

The Origin of Stylistic Word the word style is derived from the Latin word stilus which means the tool (sharp edges) used to write on sheets of wax-coated paper (Scott 1990: 279).

Leech dan Michael Short (1984: 13) also suggests that stylism is the study of literary discourse from linguistic orientation and is a link between literary criticism on the one hand and linguistics on the other.

The Purpose of Stylistic Studies

a. The Origin of the word Stilistika

Leech dan Michael Short (1984:13) says that the aim of literary stylistics is torelatethecritic'sconcern of aesthetic appreciation with the Linguist'sconcern of linguistic-description.

b. The Nature of Language Style

To make a good work and acceptable to the public, the writers or lyricists or a composer use many different styles of language, in addition, to beautify his work, as well as to reveal the contents of the mind and soul of the self-author in his work. In accordance with Keraf's disclosed that "the style of language is a way of expressing the mind through language typically showing the soul and personality of its author" (Keraf 2000: 113).

In addition, still, on the definition of language style, Dale in Tarigan explains that: "language style is a wonderful language used to enhance the effect by introducing and comparing a thing or thing with a more general object or another thing.

2. Mandar Literature

The emergence of Mandar literature along with the development of culture and civilization among the Mandar. Since Mandar tribe has been using the literature-work art. as one complement their tradition .in terms of education, marriage, religion, and entertainment But initially they are not aware of it, as the flow and continued development of the Mandar literature. then conducted a kind of literary research among the Mandar people, then they know that what they do and what they call as part of the customs of the tribe, turns out to be a rebound of literary works. The poetry of the Mandar is one of the Mandar literary works, which is a beautiful song. The poetry is often used by girls and accompanied by the rhythmic beat of tambourines as they travel around the village, at the same time they also reciprocate rhymes. In addition to poetry, the music and songs (singing) Mandar also included one type of literary works. Music and songs (singing) are classified into Mandar literature because the chant of words that are assembled into a lyric of a song whose level of literature is higher because it has represented all aspect.

a. Types of Mandar literature

a) Poetry ( Kalindaqdaq )

The term kalindaqdaq comes from the Malay language which consists of three words, which is beautiful sentences abbreviated as Kalindaqdaq ( $\mathrm{kal}=$ sentence, ndaq = beautiful, daq = beautiful). So, Kalindaqdaq is a statement of thoughts and feelings in beautiful words. In other words, Kalindaqdaq is a beautiful and rhythmic word utterance that can fascinate the listener or reader. 
b) Music and songs

Mandar's song is a rhythmic sound that uses Mandar. In Mandar is usually called Ayangan. Mandar area songs can be grouped into 2 types. First, the traditional Mandar regional song. Secondly, the song of Mandar area of new creations. The traditional Mandar area song is a song whose lyrics use the Mandar language in the form of kalindaqdaq with a rhythm known by the community as a typical Mandar rhythm. Mandar's new area song creation is a song whose verse uses Mandar language instead of kalindaqdaq with modern rhythms like dangdut, disco, jazz, and pop songs. Generally, Mandar song creations new creatives clear. These songs appear on the traditional Mandar regional song.

The Essence of Song Lyrics Song lyrics is a work that uses written a language which is usually a series of words with a beautiful diction, also using the style of language and figurative language just as well as poetry. That is, the lyrics of the song are the same as poetry when viewed on paper. As the opinion put forth by Semi in Fauzi, "The lyrics are also meant as sung poems, so they are arranged in a simple order and reveal something as simple as possible" (Fauzi, 2010: 22)

\section{METHODOLOGY}

This research used the descriptive qualitative method. Qualitative research method was a research procedure That produces descriptive data in the form of written or oral words about individual traits, circumstances, symptoms of a particular group that can be observed.

Suharsimi (2010) explainsthat "Descriptive research was a form of researchaimed to describe the phenomena that exist, both natural phenomena and man-made phenomena. The phenomenon can be the form, activity, characteristics, changes, relationships, similarities, and differences between phenomena with one another phenomena.

In this research, the researcher used the method refer. "This method was used to obtain data is done by listening to the use of spoke and wrote a language" (Mahsun, 2014: 92) .

In this case, the researcher not only listening and reading the lyrics of Mandar song but the researcher also understands first about Mandar, then proceeded to analyze the lyrics of Mandar songs that use the style of language and the meaning contained in the lyrics of Mandar song.

\section{Source Of Data}

Sources of data in this research include primary data source and secondary data, namely: The primary data source, in this case, was some lyrics of Mandar Song and the data in this research was obtained from the publication of various official organizations in the form of video and MP3. While secondary data (supporting data) are books that discuss the style of language. Then the source of data in this research was the song Mandar. The researcher used 7 lyrics Mandar song that has been researched, namely:
a. BuraqSendana,
b. Accur mareresia,
C. Andiangdaqduammu,
d. Patui sallang,
e. Usombalang sittengammu,
f. Teluk Mandar,
g. Sibaliparriq

2. The instrumentof the Research.

The instrument of the research was the researcher himself, Processed and analyzed the data in this research has been assisted by several tables that can be used, among others, the analysis of the style of language.

Tabel 1. Analysis of the Mandar Song Lyrics.

\begin{tabular}{|c|c|c|c|c|c|c|c|c|c|c|}
\hline \multirow{2}{*}{ LYRICS } & \multicolumn{7}{|c|}{ LANGUAGE STYLE } & AMOUNT \\
\cline { 2 - 11 } & 1 & 2 & 3 & 4 & 5 & 6 & 7 & 8 & 9 & \\
\hline & & & & & & & & & & \\
\hline & & & & & & & & & & \\
\hline & & & & & & & & & & \\
\hline AMOUNT & & & & & & & & & & \\
\hline
\end{tabular}


Description: (1) personification, (2) metaphors, (3) simile, (4) depersonification, (5) hyperbole, (6) parallelism, (7) alliteration, (8) asonance, and (9) repetition.

Instrument usage instructions!

$\checkmark=$ Indicates the used of language style in Mandar song lyrics

- = Indicates the absence of language style in Mandar song lyrics

3. Technique of data collection

Techniqueof data collection that used was the technique of documentation and writing technique. This technique is used to obtain data related to the style of language in the lyrics of the song. The main data of this research is the lyrics of Mandar song.

4. Technique of Data Analysis

The data in this research was analyzed in terms of language style, in accordance with the theory that supports these aspects. After getting the results of the analysis of the lyrics of the song used as the object of research, then the lyrics of songs that have been analyzed and known in terms of using the style language in Mandar.

\section{FINDINGS AND DISCUSSIONS}

The data used in this research was the lyrics of Mandar songs that are randomly selected from some singers amounted to 7 . The lyrics used in this research were as follows:

1. BuraqSendana,

2. Accur mareresia,

3. Andiangdaqduammu,

4. Patui sallang,

5. Usombalang sittengammu,

6. Teluk Mandar,

7. Sibaliparriq.

Furthermorethe six Mandar songs had been analyzed into the following language styles:

1. In BuraqSendana lyrics there were 37 language styles consisted of 3 styles of personification language, 8 hyperbolic language styles, 2 parallelism styles, 16 assonance and 8 repetition styles.

2. In the lyric of the song entitled Accuraq Marere Sia there were 25 language styles consisting of 1 style of personification language, 2 metaphorical language styles, 3 simile language styles, 3 hyperbolic language styles, 3 parallelism language styles, and 13 assonantion language style.

3. In the lyric of the song entitled Andiang Daq Duammu there were 22 styles of language consisting of 1 style of personification language, 2 style of depersonative language, 6 hyperbolic languangestyle, 1 parallelism language style, 11 assonance language style and 1 repetition language style.

4. In the lyrics of the song entitled Pattui Sallang there were 27 language style consisting of 2 styles of personification language, 1 simile language style, 1 depersonative language style, 6 hyperbolic language styles, 1 parallelism language style, 12 assonance language styles and 4 repetitions.

5. In the lyrics of the song entitled $U$ sombalangsittengammu there were 35 language styles consisting of 2 styles of personification language, 2 depersonative language style, 6 hyperbolic language styles, 3 alliteration language styles, 19 assonance language style and 3 repetition language style.

6. In the lyrics of the song entitled Teluk Mandar there was 29 language style consisting of 2 styles of metaphorical language, 4 simile language style, 7 hyperbolic language style, 2 parallelism language style, and 14 assonance language style.

7. In the lyrics of the song entitled Sibaliparriq there was 35 language style consisting of 1 style of personification language, 2 metaphorical language style, 2 simile language style, 3 depersonative language style, 6 hyperbolic language style, 1 parallelism language style, 2 alliteration language style and 18 assonance language style.

After analyzing the seventh songs it can be found that the dominant style of assonance, hyperbola, and repetition used it in the lyrics of mandar songs. it canbe seen in the following comparison table: 
Table 4.8 Language Style Comparison.

\begin{tabular}{|c|c|c|c|c|c|c|c|c|c|c|c|}
\hline \multirow{2}{*}{ No } & \multirow{2}{*}{ Song title } & \multicolumn{9}{|c|}{ Language style } & \multirow{2}{*}{$\begin{array}{c}\text { Amoun } \\
t\end{array}$} \\
\hline & & 1 & 2 & 3 & 4 & 5 & 6 & 7 & 8 & 9 & \\
\hline 1 & BuraqSendana & 3 & & & & 8 & 2 & & 19 & 8 & 40 \\
\hline 2 & Accur Marere Sia & 1 & 2 & 3 & 1 & 2 & 1 & & 13 & & 23 \\
\hline 3 & $\begin{array}{l}\text { Andiang Daq } \\
\text { Duammu }\end{array}$ & & & & 3 & 6 & 1 & & 11 & 1 & 22 \\
\hline 4 & Patui Sallang & 2 & & 1 & 1 & 11 & 1 & & 12 & 4 & 32 \\
\hline 5 & $\begin{array}{l}\text { U Sombalang } \\
\text { Sittengammu }\end{array}$ & 1 & & & 2 & 5 & & 3 & 20 & 3 & 34 \\
\hline 6 & Teluk Mandar & & 2 & 2 & & 5 & 1 & & 15 & 1 & 26 \\
\hline 7 & Siwaliparriq & 1 & 2 & 1 & 3 & 6 & 1 & 1 & 19 & & 34 \\
\hline \multicolumn{2}{|c|}{ Amount } & 8 & 6 & 7 & 10 & 43 & 7 & 4 & 109 & 17 & 211 \\
\hline
\end{tabular}

Source: Results of Data, 2016.

Description: (1) personification, (2) metaphors, (3) simile, (4) depersonification, (5) hyperbole, (6) parallelism, (7) alliteration, (8) assonance, and (9) repetition.

The language style of assonance, hyperbola, and repetition was often used by the singer to gave beauty in the language he used.

The style of the language of the assonance often arises because the use of vowels in the lyrics of the song was very much, the style of hyperbolic language also oftenarises because the singer wants to give emphasis on a statement or situation to intensify, improved the impression and influenced and style of repetition alsooften appear in because the singer wants to give the impression and reinforce what he wants to convey.

Other language styleswas not often used because the singer wants to emphasize a statement or situation to intensify, enhance his impression, influenced and reinforced what he wants to say.

\section{E. CONCLUSIONS AND SUGGESTIONS}

1. Conclusion

Based on the results of the analysis conducted by the researcher about the use of language style in lyrics Mandar. Of the sixth songs were analyzed, there were 211 language styles consisting of 8 personate language styles, 6 metaphorical language style, 7 simile language styles, 10 depersonative language style, 43 hyperbolic language styles, 7 parallelism language style, 4 alliteration language style , 109 asonance language style and 17 repetition language style.

2. Suggestion

Based on the conclusions of the research that has been described the researcher, the researcher propose some suggestions as follows:

a. It is expected that lovers of Mandar songs can know the meaning contained in the song.

b. The lovers of Mandar songs that are still teenagers so as not to forget the local language because the local language will be extinct if no longer make it as a spoken language.

Thus the conclusions and suggestions that the researcher pointed out may be able to contribute and be a reference material.

\section{REREFENCES}

[1] Chaer. 2002. Pokoknya kualitatif. Jakarta: PT. Kiblat Buku Utama.

[2] Fauzi,2010. Perbandingan Gaya Bahasa dan Bahasa Kiasan Lirik Lagu Peterpan dalam Album Alexandria dengan Lirik Lagu Ungu dalam Album Melayang Serta Aplikasinya dalam Pembelajaran 
Bahasa Indonesia di SMA, Skripsi, Jakarta: UHAMKA

[3] Keraf, Gorys. 2014.Diksi dan Gaya Bahasa. Jakarta: GramediaPustakaUtama.

[4] Kridalaksana, Harimukti.1984. Kamus Linguistik.Bandung: Gramedia.

[5] Leech,G.N.danShort,M.H.(1984).StyleinFiction.LondonandNew York: Longman.

[6] Mahsun,.2014. Metode Penelitian Bahasa. Jakarta: Rajawali Pers.

[7] Suharsimi, Arikunto 2010. Prosedur Penelitian "Suatu Pendekatan Praktik". Jakarta : Pt. Rineka Cipta

[8] Scott, A.F. 1980. Current Literary Terms. A Concise Dictionary London: The Macmillan Press Ltd

[9] Tarigan, HenryGuntur.2009. Pengajaran Gaya Bahasa. Bandung: Angkasa.

[10] Tarigan, HenryGuntur.2009. Pengajaran Semantik. Bandung: Angkasa

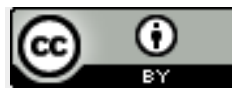

This work is licensed under a Creative Commons Attribution 4.0 International License. 